\title{
Morphometric Investigation of the Brain of West African Dwarf Sheep in Nigeria
}

\author{
Investigación Morfométrica del Encéfalo \\ de la Oveja Enana del Oeste Africano en Nigeria
}

Olopade, James Olukayode; Onwuka, Silas Kalu; Balogun, Babatunde Abiodun \& Oke, Bankole Olusiji

OLOPADE, J. O.; ONWUKA, S. K.; BALOGUN, B. A. \& OKE, B. O. Morphometric investigation of the brain of West African dwarf sheep in Nigeria. Int. J. Morphol., 23(2):99-104, 2005.

SUMMARY: Morphometric studies were carried out on the brains of twenty West African Dwarf (WAD) sheep using frozen unfixed specimen. The mean brain weight was $69.14 \mathrm{~g}$, while the mean brain length and depth were $7.48 \mathrm{~cm}$ and $4.17 \mathrm{~cm}$, respectively. The mean length of the cerebrum and cerebellum were $5.08 \mathrm{~cm}$ and $2.27 \mathrm{~cm}$, respectively.

The relative brain weight was $0.08 \%$ while the relative weight of the head was $0.8 \%$. There was a significant difference $(\mathrm{p}<0.05)$ in the weight of head, weight of brain, brain length and depth and in the relative brain weight of animals weighing 10kg and above, compared with those below this weight mark. The values of the first four parameters were higher while the fifth was lower. Animals aged one year and above, had significantly heavier body weights and longer cerebrum $(\mathrm{p}<0.05)$, than those below this age mark, the latter however had significantly lower relative brain weight and also weight of brain to weight of head.

The results obtained in this study will be useful in Comparative Neuroanatomy and as baseline research data in neuropathology, pharmacology, anaesthesiology and neurophysiology.

KEY WORDS: Anatomy; Brain; West African dwarf sheep.

\section{INTRODUCTION}

Africa has a population of 205 million sheep, approximately $17 \%$ of the world's total (FAO, 1990). The population of sheep in sub-sharara Africa is estimated at 127 million (Winrock International, 1992) and that of African humid tropics at over 20 million with about $80 \%$ of these in Nigeria (Charray et al., 1992, Gatenby, 2002).

The WAD sheep are scavengers and can tolerate a lot of diseases and harsh environmental conditions where other breeds would not thrive. For instance, the breed is known to be tolerant to trypanosomasis (Rege, 1992). WAD and can survive the cold and rains that sometimes characterize the weather in the tropics whereas to caprine counterpart, the WAD goat easily gets knocked off and comes down with diseases like PPR, etc.

The WAD sheep measure $40-60 \mathrm{~cm}$ at withers with ewes weighing $20-30 \mathrm{~kg}$ and rams $25-35 \mathrm{~kg}$ (Charray et al., Gatenby).
Sheep farming as a component of the livestock industry is extensively practiced in developed countries specifically for its products of meat, wool and other fibers. In the laboratory, sheep have also been used as models for variety of research enquires including nutrition, reproduction and disease processes. Infact, only recently (Gatenby), the world of biotechnology reverberated at the birth of the first ever cloned animal Dolly the sheep in Scotland, in 1997. Unfortunately, not much research has been carried out on sheep in Nigeria and particularly the WAD sheep. Not much information is therefore available in the literature concerning this breed (Charray et al.; Ademosun, 1992).

Morphometry is the scientific study of the dimensions of gross anatomical structures of organisms, with particular reference to their linear measurements and weights. These had often been done by direct measurements on formalin fixed specimens, especially on the brain. Results have varied and accuracies are still being discussed (Peters et al., 1998; 
2000). Although the Magnetic Resonance Imaging technique pronounces to yield more accurate and acceptable results, it is expensive and still not universally available. We recently developed a method of using frozen unfixed brain sections for these measurements (Olopade \& Onwuka, 2002; Onwuka et al., 2003) and found this to yield more close to life dimensions as it eliminates most of the short comings, such as shrinkage and distortions associated with chemical fixation. We embarked on these series of studies with the aim of providing more animal data, for more productive correlative analysis of allometric studies on humans (Kawakami, 1994) and also to provide a database of normal baseline information on the brains of small ruminants in Nigeria, in the wake of the emergence of such encephalopathies like Bovine Spongiform Encephalomyelitis (BSE) and Scrapie.

\section{MATERIAL AND METHOD}

Twenty heads, severed at the occipito atlantal joint were obtained from freshly slaughtered WAD sheep. The heads were immediately put in the ice pack buckets and taken to freezers in the laboratory which had been set at $-20^{\circ} \mathrm{C}$ for at lest 48 hours. The heads were later brought out and further processing was as previously described (Olopade \& Onwuka), which briefly are:

1. Heads were allowed to thaw for not more than 90 minutes.

2. Each head was marked with a piece of chalk to indicate a median plane. This was done by drawing a line from the foramen magnum to between the horns dorsally, to the muzzle rostrally and then caudally on the ventral surface to meet the foramen magnum - all in the median plane.

3. Each head was put in a dorsoventral position with an assistant holding the horns with his ipsilateral hand. A sharp knife was used to cut the skin at drawn line at the dorsum of the head and strong sharp hand saw to cut via the projection of the external occipital crest.

4. The cutting was stopped after a significant depression in the cranium was made in the area between the horns.

5. A sharp-edged moderately thick and strong knife was fixed in the depression and banged steadily and consistently using a mallet until two equal halves of the head was produced

Fig. 1a

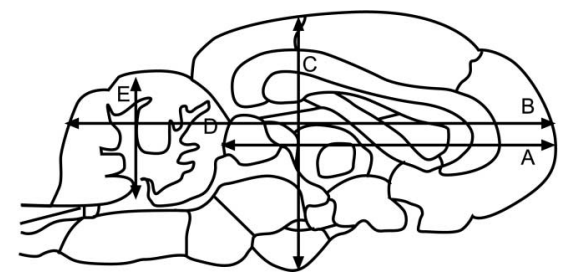

Schematic diagram of the brain of WAD sheep showing landmarks used for morphometry

A-LOC, B-LOB, C-DOB
(The perfect half was not obtained in the nasal and face regions but easier to produce at the cranium).

6. Normal saline was also used to flush the medial surface of the halves. Using a twine with a needle at one end, measurements like length and depth of some parts of the brain were taken after the cut. These included the length and depth of brain, length of cerebrum and length and depth of cerebellum.

7. The halves were left for 20-30 minutes to thaw after the cut, not exceeding this so as to prevent over-softening of the brain.

8. The edges of the brain were dug round by blunt dissection. This was done by starting from dorsal middle portion of the cerebrum under the cranium and the meninges, teased towards the cerebellum and back to the olfactory lobe. A similar procedure was followed ventrally from the area of the medulla oblongata to the infundibular stalk and from the olfactory lobe to the optic chiasma. At the rostroventral portion of the olfactory lobe a greater force was exerted due to the connection of the lobe via the cribriform plate of the ethmoid bone with olfactory nerves. Behind the cerebrum in front of the cerebellum, the tentorium was lifted up and scooped out with the cerebellum by the use of scalpel to push them from beneath the occipital condyle into the dish. The meninges and adjacent cranial nerves were left.

9. The scalpel was then inserted into the dorsal wall of the cerebrum and probed left and right into the cranium into the lateral walls of the brain and then scooped out gently into a dish. After the general scooping, the portion of the olfactory lobe left in the depression rostral to the wing of the presphenoid was also scooped out, as was the hypophysis from the sella turcica and any other part of the brain that was attached to the meninges.

10. Water, blood and fluid defrosting from the head that entered into the dish were drained.

The brain was measured using linear instruments based on the landmark in Figure 1 and specimen weighed using a Microwa Swiss ${ }^{\circledR}$ digital weighing machine.

All values obtained were presented as mean $\pm \mathrm{SD}$ and statistical analysis using the student's t-test at the 5\% level of significance.

Fig. 1b

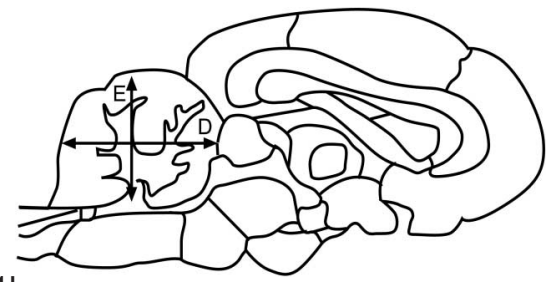

Schematic diagram of the brain of WAD sheep showing landmarks used for morphometry

D-LOCR, E-DOCR 


\section{RESULTS}

Table I. Dimensions of the unfixed brain of West African Dwarf Sheep. $n=20$

\begin{tabular}{cccccccccc}
\hline WOA & WHO & WOB & LOB & LOC & LOCR & DOB & DOCR & WOB/ & WOB/ \\
$(\mathrm{kg})$ & $(\mathrm{kg})$ & $(\mathrm{g})$ & $(\mathrm{cm})$ & $(\mathrm{cm})$ & $(\mathrm{cm})$ & $(\mathrm{cm})$ & $(\mathrm{cm})$ & WOA & WHO \\
10.85 & 0.92 & 69.14 & 7.48 & 5.08 & 2.27 & 4.17 & 2.21 & 0.008 & 0.085 \\
\pm 5.72 & \pm 0.33 & \pm 10.16 & \pm 0.54 & \pm 0.49 & \pm 0.30 & \pm 0.28 & \pm 0.41 & \pm 0.004 & \pm 0.041 \\
\hline
\end{tabular}

Table II. Dimensions of the unfixed brain of West African Dwarf Sheep, based on weight.

\begin{tabular}{lcccccccccr}
\hline & $\begin{array}{c}\text { WOA } \\
(\mathrm{kg})\end{array}$ & $\begin{array}{c}\text { WHO } \\
(\mathrm{kg})\end{array}$ & $\begin{array}{c}\text { WOB } \\
(\mathrm{g})\end{array}$ & $\begin{array}{c}\text { LOB } \\
(\mathrm{cm})\end{array}$ & $\begin{array}{c}\text { LOC } \\
(\mathrm{cm})\end{array}$ & $\begin{array}{c}\text { LOCR } \\
(\mathrm{cm})\end{array}$ & $\begin{array}{c}\text { DOB } \\
(\mathrm{cm})\end{array}$ & $\begin{array}{c}\text { DOCR } \\
(\mathrm{cm})\end{array}$ & $\begin{array}{r}\text { WOB/ } \\
\text { WOA }\end{array}$ & $\begin{array}{c}\text { WOB/ } \\
\text { WOH }\end{array}$ \\
$\geq 10 \mathrm{~kg}$ & $15.20^{*}$ & $1.13^{*}$ & $73.8^{*}$ & $7.78^{*}$ & $5.30^{*}$ & 2.28 & $4.33^{*}$ & 2.17 & 0.005 & 0.069 \\
& \pm 4.78 & \pm 0.30 & \pm 9.45 & \pm 0.51 & \pm 0.40 & \pm 0.29 & \pm 0.24 & \pm 0.46 & \pm 0.001 & \pm 0.015 \\
$<10 \mathrm{~kg}$ & 6.50 & 0.72 & 64.30 & $7.18^{* *}$ & 4.86 & 2.26 & 4.00 & 2.25 & $0.0018^{*}$ & 0.092 \\
& \pm 2.07 & \pm 0.22 & \pm 8.75 & \pm 0.49 & \pm 0.40 & \pm 0.93 & \pm 0.22 & \pm 0.38 & \pm 0.004 & \pm 0.053 \\
\hline
\end{tabular}

Table III. Dimensions of the unfixed brain of West African Dwarf Sheep, based on sex.

\begin{tabular}{|c|c|c|c|c|c|c|c|c|c|c|}
\hline & $\begin{array}{c}\text { WOA } \\
(\mathrm{kg})\end{array}$ & $\begin{array}{c}\text { WHO } \\
(\mathrm{kg})\end{array}$ & $\begin{array}{c}\text { WOB } \\
(\mathrm{g})\end{array}$ & $\begin{array}{l}\text { LOB } \\
(\mathrm{cm})\end{array}$ & $\begin{array}{l}\text { LOC } \\
(\mathrm{cm})\end{array}$ & $\begin{array}{c}\text { LOCR } \\
(\mathrm{cm})\end{array}$ & $\begin{array}{l}\text { DOB } \\
(\mathrm{cm})\end{array}$ & $\begin{array}{c}\text { DOCR } \\
(\mathrm{cm})\end{array}$ & $\begin{array}{l}\text { WOB/ } \\
\text { WOA }\end{array}$ & $\begin{array}{l}\text { WOB/ } \\
\text { WOH }\end{array}$ \\
\hline \multirow{2}{*}{ Male } & 10.60 & 0.995 & 68.70 & 7.46 & 5.00 & 2.39 & 4.09 & $2.09 * *$ & 0.007 & $6.64 \mathrm{E}-02$ \\
\hline & \pm 4.81 & \pm 0.32 & \pm 11.22 & \pm 0.38 & \pm 0.62 & \pm 0.87 & \pm 0.26 & \pm 0.52 & \pm 0.002 & \pm 0.05 \\
\hline \multirow[t]{2}{*}{ Female } & 11.10 & 0.850 & 69.58 & 7.50 & 5.16 & 2.15 & 4.24 & 2.33 & 0.009 & 0.08 \\
\hline & \pm 6.77 & \pm 0.34 & \pm 9.57 & \pm 0.68 & \pm 0.34 & \pm 0.30 & \pm 0.29 & \pm 0.24 & \pm 0.005 & \pm 0.04 \\
\hline
\end{tabular}

Table IV. Dimensions of the unfixed brain of West African Dwarf Sheep, based on age.

\begin{tabular}{|c|c|c|c|c|c|c|c|c|c|c|}
\hline & $\begin{array}{c}\text { WOA } \\
(\mathrm{kg})\end{array}$ & $\begin{array}{c}\text { WOH } \\
(\mathrm{kg})\end{array}$ & $\begin{array}{c}\text { WOB } \\
(\mathrm{g})\end{array}$ & $\begin{array}{c}\text { LOB } \\
(\mathrm{cm})\end{array}$ & $\begin{array}{c}\text { LOC } \\
(\mathrm{cm})\end{array}$ & $\begin{array}{c}\text { LOCR } \\
(\mathrm{cm})\end{array}$ & $\begin{array}{c}\text { DOB } \\
(\mathrm{cm})\end{array}$ & $\begin{array}{c}\text { DOCR } \\
(\mathrm{cm})\end{array}$ & $\begin{array}{l}\text { WOB/ } \\
\text { WOA }\end{array}$ & $\begin{array}{l}\text { WOB/ } \\
\text { WOH }\end{array}$ \\
\hline \multirow[t]{2}{*}{$1 \mathrm{yr}$} & $13.67 *$ & $1.13 *$ & 10.42 & 71.40 & 7.73 & $5.32 *$ & 4.23 & 2.13 & 0.006 & 0.07 \\
\hline & \pm 5.46 & \pm 0.27 & \pm 71.40 & \pm 10.42 & \pm 0.49 & \pm 0.27 & \pm 20.36 & \pm 0.45 & \pm 0.001 & \pm 0.01 \\
\hline \multirow{2}{*}{$1 \mathrm{yr}$} & 6.33 & $0.66^{* *}$ & 64.34 & 7.16 & 4.83 & 2.24 & 4.07 & 2.31 & 0.011 & $0.10^{*}$ \\
\hline & \pm 2.12 & \pm 0.21 & \pm 8.67 & \pm 2.92 & \pm 0.52 & \pm 0.91 & \pm 0.17 & \pm 0.38 & \pm 0.006 & \pm 0.05 \\
\hline \multicolumn{11}{|c|}{$* *$ Strong positive correlation $*$ Significantly higher at $\mathrm{p}<0.05$} \\
\hline & WOA & \multicolumn{3}{|c|}{$=$ Weight of animal } & \multicolumn{2}{|r|}{ LOCR } & \multicolumn{4}{|c|}{$=$ Length of cerebellum } \\
\hline & WOH & \multicolumn{3}{|c|}{$=$ Weight of head } & \multicolumn{2}{|r|}{ DOB } & \multicolumn{4}{|c|}{$=$ Depth of brain } \\
\hline & WOB & \multicolumn{3}{|c|}{$=$ Weight of brain } & \multicolumn{2}{|r|}{ DOCR } & \multicolumn{4}{|c|}{$=$ Depth of cerebellum } \\
\hline & LOB & \multicolumn{3}{|c|}{$=\quad$ Length of brain } & \multicolumn{2}{|r|}{ WOB/WOA } & \multicolumn{4}{|c|}{$=$ Ratio of weight of brain and weight of animal } \\
\hline & LOC & \multicolumn{3}{|c|}{$=$ Length of cerebrum } & \multicolumn{2}{|r|}{ WOB/WOH } & \multicolumn{4}{|c|}{$=$ Ratio of weight of brain and weight of head } \\
\hline
\end{tabular}

The mean brain weight (WOB) was $69.14 \mathrm{~g}$, while the mean weight of head $(\mathrm{WOH})$ was $0.92 \mathrm{~kg}$. The mean weight of the animals (WOA) was $10.85 \mathrm{~kg}$. The mean ratio of weight of brain to weight of animal (WOB/WOA) and also weight of brain to weight of head (WOB/WOH) were 0.008 and 0.08 , respectively.

Animals weighting $10 \mathrm{~kg}$ and above had significantly higher body weight, WOH and WOB $(\mathrm{p}<0.05)$ than animals weighing less than $10 \mathrm{~kg}$. They also showed significantly higher values in length of brain (LOB) brain depth (DOB) and cerebellar length (LOCR) but had a significantly lower WOB/WOA value. There was a strong positive correlation in the length of brain between animals in these weight categories.

On the average, the females were heavier in weight than the males, had heavier brains but lighter head weights. These values were however not significant $(\mathrm{P}<0.05)$. There was a strong positive correlation between the depth of cerebellum for both sexes.

Animals aged one year and above were significantly heavier than those below the age mark $(\mathrm{p}<0.05)$. They also had significantly heavier heads $(\mathrm{p}<0.05)$ and had a positive correlation in this parameter between the age groups. Animals below one year recorded significantly higher values in the WOB/WOH $(\mathrm{p}<0.05)$. 


\section{DISCUSSION}

The mean brain weight of WAD sheep in this study was found to be $69.14 \mathrm{~g}$. This is lower than the $140 \mathrm{~g}$ (nonbreed specific) in literature (Nieuwenhuys et al., 1998) and the $85.85 \mathrm{~g}$ of the Red Sokoto goat (Olopade \& Onwuka) but heavier than the $56.89 \mathrm{~g}$ of WAD goat (Onwuka et al.).

The mean brain weight ranged from 54.70g 87.20g. This was higher than that obtained for WAD goat $(49.8-77.19)$ but less than that of the dog, which ranged from 70-150g (Dyce et al., 1996). The reason for the difference with the latter was that the values recorded for dogs included several breeds.

The linear measurements of $7.48 \mathrm{~cm}, 4.17 \mathrm{~cm}$ and $2.27 \mathrm{~cm}$ were slightly longer that the $7.04 \mathrm{~cm}, 4.14 \mathrm{~cm}$ and $2.26 \mathrm{~cm}$ of WAD goat, but shorter than the $10.19 \mathrm{~cm}$, $4.67 \mathrm{~cm}$ and $2.83 \mathrm{~cm}$ of the Red Sokoto goat, respectively (Olopade \& Onwuka and Onwuka et al.).

This results in summary shows that the brain of the WAD sheep on the average is bigger than that of the WAD goat but smaller that that of the Red Sokoto goat.

The relative brain weight of $0.8 \%$ for WAD sheep was higher that the $0.6 \%$ obtained for WAD goat and Red Sokoto goat (Onwuka et al.) but lower than the $2 \%$ obtained in man (Dyce et al.). This is a function of the relatively low brain weight of the small ruminants (Olopade \& Onwuka).

Animals weighting $10 \mathrm{~kg}$ and above had significantly higher values of brain weight, brain length and depth and cerebral lengths. This suggested that as the animals grow into this weight category, the cranium and brain continue to grow in length and depth and the size of the brain increases. The shorter cerebellar depth of animals of weight $10 \mathrm{~kg}$ and above, may however suggest that some level of compression takes place along the depth of the cerebellum as the animal grows. The significantly higher value of the relative brain weight in animals below $10 \mathrm{~kg}$ suggests that even, though the brain increases in size and weight as the animal grows into $10 \mathrm{~kg}$ and above, the proportional growth of the brain is far less than the growth in body weight making lighter animals to have relatively heavier brains.

The females weighed heavier than the males but had a lower head weight. WAD rams are known to have well-developed horns, which are absent in ewes (Charray et $a l$.); this is likely responsible for the heavier head inspite of the lesser body weight of the males. The females also had a heavier brain weight. This was consistent in the results obtained for WAD goats and Red Sokoto goats (Olopade \& Onwuka and Onwuka et al.) through in all the above studies, the females had higher body weights. It may however in part be due to brain loss in males as human data has shown that there is a higher loss of neocortical neurons in males than in females (Pakkenberg et al., 1997; 2003).

Animals aged one year and above had significantly higher values for body and head weight than animals below one year. This implies that there is a geometric increase in both indices at the age of one. This is about the time WAD sheep reaches puberty (Gatenby). The significantly lower relative brain weight in animals aged one year and below is possibly due to a relative reduction in brain weight after puberty in comparison to the gain in body weight. The higher cerebellar depth in animals below the age of one suggests a compression of the structure, as the animal grows older and corresponds to the same observation in this study in animals below $10 \mathrm{~kg}$ body weight. The significantly higher length of cerebrum in animals aged one and above may be explained by the post pubertal demands on memory.

The results in this study will serve as valuable tools in research into pharmacology. Doses of drugs administered to animals are based on body weight. This research has established that brain does not grow at the same rate with the body; thus a lot of idiosyncrasies have been associated with centrally acting drugs (Range et al., 1995). This may be because brain weight and other linear measurements are not considered before administration.

Also some pharmacological data in humans can be predicted using animals' data; some human values have been extrapolated based on allometric correlations between brain weight and these parameters in rat, rabbit and dog (Kawakami).

The data in this work will also be useful in neurophysiology, anaesthesiology, neuropathology, and in comparative studies among breeds of sheep in Nigeria and in the regional anatomy of the head of this breed (Salako, 2002). 
OLOPADE, J. O.; ONWUKA, S. K.; BALOGUN, B. A. \& OKE, B. O. Investigación morfométrica del encéfalo de la oveja enana del Oeste africano en Nigeria. Int. J. Morphol., 23(2):99-104, 2005.

RESUMEN: Se efectuó un estudio morfométrico en 20 encéfalos frescos, congelados de ovejas enanas del Oeste africano. El peso promedio del cerebro fue de $69.14 \mathrm{~g}$, mientras que el largo y la altura fueron de $7.48 \mathrm{~cm}$ y $4.17 \mathrm{~cm}$, respectivamente. La longitud promedio del cerebro y cerebelo de $5.08 \mathrm{~cm}$ y $2.27 \mathrm{~cm}$, respectivamente.

El peso relativo del encéfalo fue $0,08 \%$, mientras que el de la cabeza fue $0.8 \%$. Hubo diferencias significativas $(\mathrm{p}<0.05)$ en el peso de la cabeza, del encéfalo, longitud y altura del cerebro y en el peso relativo del cerebro de los animales de más de $10 \mathrm{~kg}$, si éstos son comparados con animales de menor peso. Los valores de los primeros cuatro parámetros fueron más altos, en cambio el quinto fue más bajo. Animales de un año de edad y más, tenían un cuerpo significativamente más pesado y un cerebro de mayor longitud ( $\mathrm{p}<0.05$ ) que aquellos bajo esta edad. Sin embargo, en estos últimos fue significativo un peso relativo más bajo para el encéfalo y la cabeza.

Los resultados obtenidos en este estudio pueden ser usados en Neuroanatomía Comparada y como base de datos en investigaciones de neuropatología, farmacología, anestesiología y neurofisiología.

PALABRAS CLAVE: Anatomía; Cerebro; Oveja enana del Oeste africano.

\section{REFERENCES}

Ademosun, A. A. Constraints and Prospects of Small Ruminant Research and Development in African. Proceedings of the second biennial Conference on the African small ruminant research network AICC, Arusha, Tanzania, 7-11 December, 1992.

Charray, J.; Humbert, J. M. \& Levif, J. Manual of Sheep Production in the Humid Tropics of Africa. $C A B$ International 1992.

Dyce, K. M.; Sack, W. O. \& Wensing C. J. C. Textbook of Veterinary Anatomy. 2. ed. W. B. Saunders, 1996.

FAO (Food and Agricultural Organisation of the United Nations). Production Yearbook, 44, FAO, Rome, Italy, 1990.

Gatenby, R. M. The Tropical Agriculturist, Sheep. 2. ed. Macmillan Publishers Limited, 2002.

Kawakami, J. Prediction of the brain delivery of Ofloxacin, A new quinoline in humans from animal data. $J$. of Pharmacokinetics and Biopharmaceutics 22(3):207-27, 1994.

Nieuwenhuys, R; Ten Donkelaar, H. J. \& Nicholson, C. The Central Nervous System of Vertebrates. Berlin Sponger, 1998. V. 3.

Olopade, J. O. \& Onwuka, S.K. Preliminary Morphometric Investigation of the Brain of Red Sokoto (Maradi) goat. Tropical Veterinarian 20(2):80-4, 2002.
Onwuka, S. K.; Olopade, J. O.: Babajide, B. F. \& Ehimiyien, I. O. Preliminary Morphometric Investigation of the Brain of the West African Dwarf Goat. Proceeding of the 39th Annual Conference of Nigerian Veterinary Medical Association held in Sokoto, Nigeria, 2003. pp. 57-9.

Pakkenberg, B. \& Gundersen, H. J. G. Neocortical neuron number in Human: Effect of Sex and Age J. Comp. Neurology 384:312-20, 1997.

Pakkenberg, B.; Peling, D.; Marner, L.; Bugdaard, M. J.; Gundersen, H. J. G.; Nyengaarad, J. R. \& Regeur, L. Aging and the Human Neocortex. Exp. Gerontology, 38:95-95, 2003.

Peters, M.; Jancke, L.; Staiger, J. F.; Schlaus, G,; Helang, Y \& Steinmetz, H. Unsolved problems of comparing brain sizes in homosapiens. Brain and Cognition 38:254-85, 1998.

Peters, M.; Janke, L. \& Zilles, K. Comparison of overall brain volume and Mid-Sagittal Corpus Callosum Surface Area as obtained from NMR Scan and Direct Anatomical Measures; A writer subject study on autopsy brain. Neuropsychologia 38:1375-81, 2000.

Range, H. P.; Rither, D. M. \& Dale, M.M. Pharmacology. 3. ed. Harcourt Brace and Company Limited, 1995.

Rege, J. E. O. Indigenous African small ruminants, A Case for Characterization and Improvement. Proceedings of 
OLOPADE, J. O.; ONWUKA, S. K.; BALOGUN, B. A. \& OKE, B. O.

the Second Biennial Conference of the African small ruminant research network AICC. Arusha, Tanzania 711 December, 1992.

Salako, A. E. Phenotypic variation among the West African Dwarf and Yankassa sheep of the Humid South-west Nigeria. Ph.D. Thesis, Department of Animal Science, University of Ibadan, Ibadan, Nigeria, 2002.

Winrock International Assessment of Animal Agriculture in Sub-Sahara Africa Winrock International Institute for Agricultural Development, Morrilton, Arkanses U.S.A. 1992.
Correspondence to:

Prof. Dr. James Olukayode Olopade

Department of Veterinary Anatomy

Faculty of Veterinary Medicine

University of Ibadan

Ibadan

$\mathcal{N I G E R I A ~}$

Phone:+234-8023860829

E-mail:jkayodeolopade@yahoo.com

Received: 13-12-2004

Accepted: 28-02-2005 